\title{
CONCESSÃO DA LICENÇA-MATERNIDADE REMUNERADA AO ADOTANTE SOLTEIRO
}

\author{
Isis Chagas Bitencourt ${ }^{1}$ \\ Carlos Alberto Antônio Junior ${ }^{2}$ \\ Maurício Martins Alves ${ }^{3}$
}

Resumo: O presente trabalho analisa a concessão da licença-maternidade remunerada aos adotantes solteiros, em função das novas configurações de constituição familiar no período atual. A partir de pesquisa doutrinária e artigos científicos, e priorizando a análise da legislação previdenciária e relatos de casos, tem por objetivo destacar a evolução do amparo jurídico, jurisprudencial e legislativo, conquistada pelos homens solteiros adotantes. Como resultados verificam-se as alterações recentes promovidas pela Lei 12.873/2013, além das lacunas remanescentes em contrapartida a um tratamento plenamente igualitário, concluindo, assim, que se faz necessária uma interpretação extensiva das garantias disponibilizadas às mulheres, gestantes e/ou adotantes, aos homens adotantes solteiros.

Palavras-chave: Salário-maternidade; Licença-adoção; Adoção; Adotantes homens.

\footnotetext{
1 Faculdade de Direito/UNIVAP, Brasil. E-mail: isis.chagasb@gmail.com.

2 Faculdade de Direito/UNIVAP, Brasil. E-mail: carlos.alberto.antonio.jr@gmail.com.

3 Faculdade de Direito/UNIVAP, Brasil. E-mail: mmalves@univap.br.
} 